\title{
Tahâvî'nin İstidlâlde İhtilaflı Sünnî Fırkaların Birliğine Katkısı
}

Tahavi's Contribution to the Unity of the Epistemological Disputed Sunni Sects

\section{Zekerya SARIBULAK}

Dr. Öğr. Üyesi, Hakkâri Üniversitesi, İlahiyat Fakültesi, Temel İslam Bilimleri Bölümü, Kelam Anabilim Dalı

Assist. Prof. Dr., Hakkari University, Faculty of Theology, Department of Basic Islamic Sciences, Department of Theology Hakkari/TURKEY

zekeryasaribulak@hakkari.edu.tr https://orcid.org/0000-0002-9113-6653

Doi: $10.34085 /$ buifd. 993229

\section{Öz}

Dini ilimlerin elde edilmesinde, Hz. Peygamber ve ashap döneminde herhangi bir istidlâl yöntemine ihtiyaç duyulmamıştır. Fakat hilafet sorunu siyasî kamplaşmalara yol açtı̆̆ı gibi itikadî alanda da bazı fırkaların oluşumuna zemin hazırlamıştır. Bunun yanında değişik din ve kültürlerle karşılaşma, felsefenin Arapçaya tercüme edilmesi ve diğer bazı etkenler h. I. Yüzyılın sonlarında İslam toplumunun ana gövdesinden birçok itikadî fırkanın ortaya çıkmasına sebebiyet vermiştir. Yeni oluşan bu fırkalar istidlâlde, aklî ve felsefî delilleri yoğunluklu kullandıkları için farklı görüşlere sahip olmuşlardır. Dolayısıyla ayrı birer isimle yeni birer fırka, ancak bid'at ehl-i olarak anılmışlardır. Temel esaslarda ana gövdeyle aynı görüşte oldukları için İslam ümmetinden sayılmışlardır. Büyük çoğunluk ise istidlâlde nass ile yetindiği için Sünnî olarak algılanmıştır. Fakat ayrılıkçı fırkaların yöntemleri, Sünnî çoğunluktan bir kısım ulemayı da istidlâl yönteminde yenilik yapmaya zorlamıştır. Böylece Sünnî ulema istidlâlde iki kısma ayrılmışlardır. Bir kısmı nassın yanında aklî ve felsefî delilleri de yeteri kadar kullanmışlardır. İmam Ebu Hanife ve daha sonra oluşum sürecine giren Eş'arîler ve Mâtürîdîler bunlardandırlar. Daha sonra Selefîyye adıyla anılacak olan diğer bir kısım ise ilk dönem istidlâlinde ısrarcı olmuştur. Sünnî çoğunluk bir taraftan bazı fırkaları istidlâl yöntemleri sebebiyle bid'at ehl-i sayarken aynı sebeple derinlikli ayrılıklara sebebiyet veren bu fırkayı bid'at ehl-i saymamıştır. İşte bu durumun araştırılması önem arz etmektedir. Elbette siyasî ve fıkhî bazı sebepleri vardır. Ancak bu durumun oluşmasına bazı Sünnî akaid âlimlerinin katkısı da olmuştur. Bunlardan birisi de Hanefî akaid yazarı Tahâvî’dir. Bize göre o, te'lif ettiği akaid metniyle Sünnî topluluğun Hanefîyye/Matüridîyye, Eş'arîyye ve Selefîyye'den meydana geldiği kanaatinin oluşmasında etkili olmuştur.

Anahtar Kelimeler: Kelam, Akaid, Sünnî, İstidlal Yöntemi, Ebu Hanife, Tahâvî,

\section{Abstract}

In the acquisition of religious sciences, there was no need for any method of evidentiary during the period of the prophet and his companions. However, the problem of caliphate/imam not only led to political polarizations, but also paved the way for the formation of some sects in the field of faith. In addition, encounters with different religions and cultures, the translation of philosophy into Arabic and some other factors led to the emergence of many sects from the main body of the Islamic society at the end of the 1st century of the Hijri. These newly formed sects had different views because they used rational and philosophical evidences in the evidentiary. Therefore, new sects with different names were only referred to as people of bid'at. Since they are of the same opinion with the main body in basic principles, they are considered as part of the Islamic Ummah. The majority/main body, on the other hand, was perceived as Ahl as-Sunnah/Sunni because they were content with nass in evidentiary. However, the methods of the separatist sects forced some of the ulama from the Sunni majority to innovate in the method of evidentiary. Thus, evidentiary to the Sunni ulama is divided into two parts. Some of them have used the mental and philosophical evidences sufficiently together with the nass. Imam Abu Hanifa and the Ash'aris and Maturidis, who later entered the process of formation, are among them. Another part, which would later be called the Salafiyya, insisted on the induction of the first period. While the Sunni majority considered some sects to be people of bid'ah due to their evidentiary, they did not consider this sect to be people of bid'ah, which caused deep divisions for the same reason. It is important to investigate this situation. Of course, there are some political and legal reasons. However, some Sunni scholars have also contributed. One of them is Tahavi, the author of Hanafi creed. In our opinion, he was influential in the formation of the opinion that the Sunni community is composed of Hanafîyye/Maturidiyya, Ash'ariyya and Salafiyya with the text of the creed that he wrote. 
Keywords: Kalam, Akaid, Sunni, Evidentiary, Abū Ḥanīfa, Tahavi,

\section{GİRIŞ}

Sünnîlik; fıkıhta Ehl-i hadis ve Ehl-i rey, ${ }^{2}$ itikatta ise Eş'arîyye, Mâtürîdîyye ve Selefîyye fırkalarından oluştuğu kabul edilmektedir. ${ }^{3}$ Ümmetin büyük çoğunluğuna tekabül eden bu oluşumun uleması, ilk dönemde akaid ilminin istidlâl yönteminde Kur'an ve Hz. Peygamberden gelen haberlerle yetinmişlerdir. ${ }^{4}$ Ancak hicri I. Yüzyılın sonlarına gelindiğinde, siyasî iç çekişmeler, değişik din ve kültürlerdeki toplumlarla bir arada yaşama ve felsefenin Arapçaya tercüme edilmesi gibi bazı amiller akaid ilminin istidlâl yönteminde bir yeniliğe gidilmeyi zorunlu hale getirmiştir. Nitekim Kaderiyye, Mu'tezile ve Cehmiyye gibi bazı fırkalar istidlâlde yenilik yaparak belirli birer oluşum haline gelmişlerdir. Bu fırkalar ilim elde etmeye çalışırken, akli ve felsefi delilleri yoğunluklu kullanmışlardır. Böylece menşeinde siyasî ihtilaflar olan Şîa ve Hâriciyye fırkalarıyla birlikte istidlâlden kaynaklı ihtilaflar sebebiyle de bazı fırkalar oluşum sürecine girmiştir. Muhtelif isimlerle anılan yeni fırkalar aynı zamanda ana gövdenin de Ehl-i Sünnet ve'l-Cemaat/Sünnî olarak isim almasına sebebiyet vermişlerdir. Nitekim ana gövdeye mensup alimler siyasî ve itikadî teorilerini bu süreçten sonra Sünnî çoğunluk adıyla geliştirmeye başlamışlardır. ${ }^{5}$ Böylece tarihi süreç içerisinde Sünnîlik hem Şîa ve Hâriciyye gibi siyasî fırkaların, hem de istidlâl yöntemi sebebiyle bid'at ehl-i addedilen Kaderiyye, Cehmiyye ve Mu'tezîle gibi kelamî fırkaların karşıtı olarak anılmıştır.

Sünnî düşüncesi paralelinde oluşan kelam ilminin istidlâl yönteminde nassın yanında akli delillerin de kullanılması gerektiğini dile getiren akaid âlimlerinden birisi de İmam Ebu Hanife olmuştur. O, Ehl-i Sünnet'i temsilen, bu alanın istidlâl yöntemini nass ve akli deliller ekseninde geliştirerek bir yenilik yapmıştır. Fakat bu metodu zorunluluktan geliştirdiğini, "sadece nass ile yetinemeyeceklerini"6 ifade ederken anlıyoruz. Eş'arî ve Mâtürîdî de istidlâlde onun yöntemini kullanarak $^{7}$ bu disiplini sistematik kelama dönüştürmüşlerdir. İstidlâl birliği, kelam ilminin temel esaslarında her iki ekolün görüş birliğini sağlamış ve teferruattaki ihtilafları da asgariye indirmiştir. Sonuçta her iki ekolün Sünnî oluşumun kelamî tarafını temsil ettikleri tezi kabul görmüştür. ${ }^{8}$ Ancak haberî sıfatlar hususunda te'vili kesin bir dil ile ret eden bazı hadisçiler de Sünnî oluşumun bir diğer kolu olarak kabul edilmişlerdir. Esasen istidlâl yöntemleri, onları Eş'arî ve Mâtürîdîlerle derin görüş ayrılıklarına götürmüştür. Nitekim Ehl-i sünnetten oldukları iddiasında bulanan bazıları hadisçiler, "Allah cisimdir. İnsan şeklinde bir cüssesi vardır. Etten ve kandandır. El, ayak, baş, bacak gibi organları vardır. Bir yerden bir yere intikal eder, aşağı iner, yukarı çıkar, musâfaha yapar, ihlâs sahibi insanlarla dünyada ve ahirette kucaklaşır" şeklinde görüş belirterek teşbih ve tecsîme düşenler olmuştur. ${ }^{9}$ Ayrıca başta Ahmed b. Hanbel olmak üzere ilk dönem hadisçilerin büyük bir kısmı haberî sıfatlar hususunda Mâtürîdî ve Eş'arî fırkasıyla aynı görüşte olmamışlar ve istidlâl yöntemleri sebebiyle çok derin ayrılıklar içerisinde olmuşlardır. Özellikle "istivâ" hususundaki görüşleri iki fırka arasında büyük bir farklılık arz etmektedir. ${ }^{10}$

Görüldüğü gibi Ehl-i hadisten bir kısım ulemanın istidlâlden kaynaklanan bu tür ihtilafları itikadın temel esası olan tevhit konusuyla ilgilidir. Buna rağmen Eş'arîlik ve Mâtürîdîlikle birlikte Sünnî ana gövdeyi oluşturdukları tezi kabul görmüştür. Esasen Ehl-i hadisin çoğunluğu her iki fırkayı da Sünnîliğin dışında ve bid'at ehli addederek kendilerini Sünnî topluluğun tek mümessili olarak görmüşlerdir. ${ }^{11}$ Buna rağmen Eş'arî ve Mâtürîdî kelamcılar bu fırkanın Sünnî oluşumun bir diğer tarafı olduğunu kabul etmişlerdir.

\footnotetext{
2 Abdulkahir b. Tahir b. Muhammed el-Bağdadî, el-Farku beyne'l-firak, (Beyrut: Daru'1-Kutubi'l-1̂lmiyyah, ts.), 241.

3 a.mlf., el-Fark, 241; Bekir Topaloğlu, Kelam İlmine Giriş, (İstanbul: Damla Yayınları, 20013), 145.

${ }^{4}$ Osman b. Said b. Halid ed-Darimî, es-Sicistanî, Nakdu'l-imam Ebu Said Osman b. Said âla'l-Merisî el-Cehmî el-ânid fima eftere 'al' Allahi azze ve celle mine't-tevhid, 1. Bas. (Riyad: Daru Neşr, 1998), I/214; Topaloğlu, Kelam Ilmine Giriş, 115.

${ }^{5}$ Örneğin İmam Ebu Hanife Osman el-Bettî'ye gönderdiği risalede Ehl-i sünnet ve'l-'adaleti savunduğunu dile getirmektedir. bk. Ebu Hanife Numan b. Sabit, er-Risale ilâ Osman el-betti, (el-Âlim ve'l-muteâllim adlı eser ile birlikte) thk. Muhammed Zahid elKevseri, (Kahire: 1368), 38.

${ }^{6}$ Ebu Hanife Numan b. Sabit, el-Âlim ve'l-müteâllim, Çev: Mustaafa Öz, (İstanbul: MÜİF Vakfı Yayınları, 2015), 8.

${ }^{7}$ Nass ve aklî istidlal hususunda.

8 Günümüzde Maliki, Şafiî ve bir kısım Hanbelîlerin itikadî görüşlerini Eş‘arîlik, Hanefî ekolünün itikadî tarafını da Matürîdîliğin temsil ettiği kabul edilmektedir. Ayrıntılı bilgi için, Topaloğlu, Kelam İlmine Giriş, 145.

${ }_{9}$ Muhammed b. Abdülkerim eş-Şehristanî, el-Milel ve'n-nihal, (Beyrut: Daru Marife, ts.), 1/105.

${ }^{10}$ Ayrıntılı bilgi için bk. Ahmed b. Hanbel, er-Red âla'z-zenadikâ ve'l-fima şeket fihi min müşabeheti'l-Kur'an ve te'vilihi 'ala gayri te'vilihi, 1. Bas. thk. Sabri b. Selame Şahin, (Riyad: Daru'Sıbat, 2008), 161.

${ }^{11}$ Ayrıntılı bilgi için bk. Hasan b. Ali b. Halef el-Berbeharî, Şerhu's-sünneti, 1. Bas. (Riyad: 1426), 124.
} 
Sünnî oluşuma nispet edilen bu ekollerin aynı isimle anılmasını sağlayan en önemli etkenlerden birisinin fikhî mezhep birliği bir diğeri de siyasî birliktelik olduğu bilinmektedir. Ancak bazı akaid alimlerinin de eserlerindeki istidlâl yöntemiyle bu sürece katkı sağladıkları şüphesizdir. Bize göre, bu anlamda katkı sağlayanların başında Tahâvî (öl. 321/852) gelmektedir.

İşte bu çalışmada, bazı hadisçilerin İmam Ebu Hanife'nin istidlâl yöntemi ve fıkıhta Hanefî olan Mu'tezilî kelamcıları eleştirmeleri sebebiyle, Hanefî ekolünün Sünnî oluşum ile bağlarının zayıflamasına karşın, Tahâvî'nin ekolun Sünnî isimle anılması hususuna sunduğu katkısı görülmeye çalışılacaktır. Ancak bunun görülebilmesi için Sünnî oluşumun kısa bir kronolojisinin yapılmasına ihtiyaç vardır.

\section{Sünnî Kelamın Oluşum Süreci}

Kelam mezheplerinin teşekkül sürecine girdiği h. I. Yüzyılda, Sünnî ulemanın büyük çoğunluğu, diğer dini ilimlerde olduğu gibi akaid alanında da nassı yeterli görmüş, kelam ilmiyle uğraşmayı bid'at ve kelam ehlini bid'atçllıkla suçlamıştır. ${ }^{12}$ Ancak felsefenin Arapçaya tercüme edilmesi, Irak ve Mâverâünnehir gibi bazı bölgelerde değişik din ve kültürlerin varlığını halen sürdürüyor olmaları, yöntem değişikliğini zorunlu hale getirmiştir. Nitekim Ma'bed el-Cühenî (öl. 80/699), Gaylân edDımaşkî (öl. 120/738 civarı), Cehm b. Safvân (öl. 128/745-46), Ca'd b. Dirhem (öl. 124/742), Vasıl b. Atâ (öl. 131/748) ve Amr b. Ubeyd b. Bab (öl. 144/761) gibi birçok kelamcı bu dönemde felsefî ve aklî delilleri kullanmaya başlamış ve hararetli tartışmalara girmişlerdir. Buna binaen kendilerine mütekellim, uğraştıkları disipline de kelam adı verilmiştir. ${ }^{13}$

Kelamcıların çoğu Irak Basra bölgesinde faaliyet göstermiştir. İmam Ebu Hanife de Sünnîlik kapsamında oradaki kelamî tartışmalara defalarca katılmıştır. ${ }^{14}$ Bu durum, onun Osman el-Betti'ye gönderdiği risalede, ashap ve tabiinden birçok ismi zikrettikten sonra kendisinin de onların çizgisinde Ehl-i sünnet ve'l-âdaleti temsil ettiğini ifade etmesinden anlaşılmaktadır. ${ }^{15}$ Ayrıca makālât yazarı elBağdadî, onu Ehl-i Sünnet ve'l-Cemaat'ın ilk kelamcıları arasında ${ }^{16}$ İbn Fûrek (öl. 406/1015) ise onun el-Âlim ve'l-muteâllim adlı eserine şerh yazmıştır. ${ }^{17}$ Ebü'l-Muîn en-Nesefî̀ (öl. 508/1114) de bu gerçeğe dikkat çekerek, onun fıkıhta olduğu gibi itikat alanında da mezheplerinin imamı olduğunu ifade etmiştir. ${ }^{18}$ Bunun yanında Mürcie'den sayılan Kerrâmîye fırkası ve birçok Mu'tezîle kelamcısı fıkıhta Hanefî olmalarına rağmen Hanefî nisbesiyle değil, kelamî görüşleri doğrultusunda isim almışlardır. Elbette bu durum adı geçen fırka ve kelamcıların itikat alanında ona muhalif olduklarını göstermektedir. Şayet fıkıhta olduğu gibi akaid alanında da onunla aynı görüşü paylaşmış olsalardı şüphesiz hem fıkhî hem de itikadî görüşlerine nispeten Hanefî nisbesiyle anılmış olacaklardı. Nitekim Mâtürîdî ve Tahâvî gibi bazı akaid alimleri hem itikadî hem de fıkhi açıdan Hanefî nisbesiyle anılmışlardır. İşte bu durum onun Sünnî akaid ilminin öncülerinden birisi olduğunu göstermektedir. Ancak dördüncü yüzyılda faaliyet gösteren Tahâvî ve Matüridî dönemime kadar onun görüşleri etrafında bir oluşum meydana gelmemiştir. Çünkü bu süreçte Sünnî gelenek adına kelamî bir oluşum olmamıştır. Hatta kelam ehli ve disiplini hiçbir ayırıma tabi tutulmadan bid'at addedilmiştir. ${ }^{19}$ Daha çok Mu'tezîle fırkasıyla özdeş bir disiplin olarak algılanmıştır. Irak Hanefî fıkıhçılarının büyük çoğunluğu da Mu'tezîlî bir karakterde olunca ${ }^{20}$ onun Sünnî akaid çizgisi de kısa bir süreliğine sekteye uğramıştır. Çünkü mihne, Mu'tezîle'yi toplum nezdinde istenmeyen fırka durumuna düşürünce

\footnotetext{
${ }^{12}$ Ebu Hamid Muhammed b. Muhammed el-Gazzalî, Kanunu't-te'vil, thk. Muhammed Zahid el- Kevseri, (Kahire: Matbaatu Envar, 1940), 7.

${ }^{13}$ Ayrıntılı bilgi için bk. Mustafa Aburezzak, Temhidun li tarihi'l-felsefeti'l-İslamiyye, (Kahire: Mektebetu İskenderiyye, 2010), 265268.

14 İbn Hacer Ahmed el-Mekkî, el-Hayratu'l-hisan fi menakibi'l-imami'l-ấzam Ebu Hanifetu'n Nu'man, (Bombay: 1324), 27.

${ }^{15}$ Ebu Hanife Numan b. Sabit, er-Risale, thk. Muhammed Zahid el-Kevseri, (el-Âlim ve'l-muteâllim adlı eser ile birlikte) (Kahire: 1368), 38.

${ }^{16}$ Bağdadî, el-Fark, 241.

${ }^{17}$ Mektebetu's-Sakâfeti'd-Diniyye tarafında Kahire'de Ahmed Abdurrahim es-Sayih'in tahkikiyle 2008'de basılmıştır.

${ }_{18}$ Meymun b. Muhammed Ebu'l-Muîn en-Nesefî, Tabsiratu'l-edille fi usuli'd-din, thk. Hüseyin Atay, (Ankara: DíB Yayınları, 2004), $1 / 405$.

${ }^{19}$ Ayrıntılı bilgi için bk. Süleyman Feyyad, “el-Eimmetu'l-erbaa” Kitabu'd-devha, (Katar: Vezaretu's-Sâkâfeti ve'1-Fünun ve'tTüras), 16.

${ }^{20}$ Cağfer Karadaş, Ana Hatlarıla Kelam Tarihi, (İstanbul: Ensar Neşriyet, 2017), 183.
} 
Mu'tezîlî kelamcılarının fıkıhta tabi oldukları Hanefî fıkıh mezhebi (dolayısıyla mezhep imamının itikadî görüşleri) de olumsuz etkilenmiştir. ${ }^{21}$

Mu'tezîle mihnesinden sonra, Abbasi halifesi Mütevekkil'in desteğiyle kelam disiplini ve kelamcları bir bütün olarak hedef alan Ahmed b. Hanbel ve takipçisi Selefiyye fırkası, Sünnîliğin hamiliğini yapmış ve kendileri dışında kalan diğer mezhep müntesiplerini bid'at ehli addetmişlerdir.22 Böylece mihne öncesinde faal olan, eser te'lif eden, oluşum adına kelam tartışmalarına giren İmam Ebu Hanife'nin kelamî yönü görmezden gelinmiş, siyasîler ve karizmatik bazı alimler tarafından toplumdan izole edilmeye çalışılmış ve kelam çizgisi bir bütün olarak Sünnî toplumun dışında gösterilmeye çalışılmıştır. Hatta bu süreçte kelam ve kelamcılar bir bütün olarak zem edilmiştir. Öyle ki hadis ehline daha yakın addedilen Abdullah b. Küllâb (öl. 240/854), Hâris el-Muhâsibî (öl. 243/857) ve Hüseyn b. Ali el-Karabisî (öl. 248/862) gibi bazı Sünnî kelamcilar da Ahmed b. Hanbel'in eleştirilerine maruz kalmışlardır. ${ }^{23}$ Böylece mihneden sonra Sünnî oluşum, kelama mesafeli duran Ahmed b. Hanbel ve onun yöntemini esas alanlardan ibaret görülünce, Sünnîlik kavramı, istidlâlde nassla birlikte aklî ve felsefî delilleri de kullanan diğer fırkaları da içine almayan bir kavram gibi algılanmış ve sadece Ehl-i hadisi içine alan bir kavram olarak algılanmıştır. İşte İmam Tahâvî'nin, Hanefî liğin Sünnî oluşumun bir parçası olduğu yönünde gösterdiği çaba ve İmam Ebu Hanife ve diğer imamları öncelemesi, onun yönteminin büyük çoğunluk tarafından kabul görmesine katkı sağlamıştır. Böylece Mâtürîdî ve Eş'arî fırkalarının da Sünnî topluluğun büyük bir parçası oldukları hususuna da katkı sağlamıştır.

\section{Tahâvî, İlmi Kişiliği ve Sünnî Birliğe Katkısı}

Ebu Hanife'den sonra, genelde Sünnî kelamın, özelde Sünnî Hanefî kolu kelamının zemin bulması ve gelişmesinde etkili olan akaid âlimlerinden birisi Tahâvî'dir. O fıkıh ve itikatta Ebu Hanife'ye tabiiyetini açık bir şekilde dile getirmiştir. İlk olarak annesi ve babasından Kur'an ilimleri ve âdâb derslerini ${ }^{24}$ daha sonra uzun bir müddet, dayısı ve aynı zamanda İmam Şafiî́nin öğrencisi ve görüşlerinin râvisi Müzenî'den ilim tahsil etmiştir. Şafiî̀nin es-Sünnen adlı eserini, hadis, rical ilimleri ve karşılaştırmalı Şafiî fıkhını da ondan almıştır. Ayrıca onun geniş kütüphanesinden yararlanmış ve Hanefî mezhebine geçene kadar da yanından ayrılmamıştır. ${ }^{25}$ Misır hükümdarı Ahmed b. Tolun'un fıkhî bir meseleyi tartışmak üzere gönderdiği Şam bölgesi ve dönüşte uğradığı Kudüs, Gazze, Askalân ve Dımaşk idarî seferleri' ${ }^{26}$ haricinde, Mısır'ın dışına çıktığına dair bir kayıt da bulunmamaktadır.

Tahâvî'nin itikadî görüşlerinin şekillenmesinde ailesinden aldığı ilk eğitim etkili olmuştur. Ayrıca ders aldığı diğer hocalarının tamamına yakını da aynı gelenekten geldikleri görülmektedir. Aşağıda görüleceği gibi onun hocalarının her birisi hadis ilmiyle iştigal ettiği bilinen şahsiyetlerdir. İbrahim $b$. Ebu Davud Süleyman b. Davudi'l-Esedî Ebu İshak el-Berlisî, ${ }^{27}$ Ahmed b. Şuayb b. Ali en-Nesaî (ö. 303), ${ }^{28}$ Ahmed b. Ebu Îmrani'l-Kadi (ö. 280) Ebu Cafer el-Bağdadî, ${ }^{29}$ İsmail b. Yahya el-Müzenî (ö.

\footnotetext{
${ }^{21}$ Ayrıntılı bilgi için bk. Hatib Bağdadi, Ebu Bekir Ahmed b. Ali b. Sabit (öl. 463/1070), Tarihu Medineti's-selam tarihu Bă̆dad, (İbnu'n-Neccarın Zeylli tarihu Bağdad ve İbnu Dimyatî'nin el-Müstefâd min zeyli tarihi Bağdadî ile birlikte), thk. Beşşar Avvâd Ma'ruf, (Beyrut: Daru'l-Garbi'l-İslamî, 1422/2001. 27/518.

${ }^{22}$ Feyyad, Kitabu'd-dahve, 16.

${ }^{23}$ Ayrıntılı bilgi için bk.; İsmail b. Kesîr, el-Bidâye ve'n-nihâye, (Beyrut: Mektebetu'l-Maârif, ts.), 10/329. İbn Kesir adı geçen eserinde, Ahmed b. Hanbel'in, Muhasîbîyi dinleyip vaazlarından etkilenip ağladığı halde yine insanları onun kitaplarını okumaktan med ederdi, nitekim Ebu Zür'a el-Mühâsibî'nin eserlerinin içeriğini bid'at ile itham ediyordu, demektedir. Dolayısıyla Ahmed b. Hanbel'in kelam disiplinine karşı herhangi bir ayırıma gitmeden bir bütün olarak tavır almıştır denilebilir.

${ }^{24}$ Abdülkādir b. Muhammed b. Nasrullah el-Kureşî, el-Cevahiru'l-muzia fi tabakâtı'l-Hanefiyye, thk. Abdulfettah el-Hulvu, İsa el-Halebî, (Kahire: 1398), 1/274.

${ }^{25}$ Taceddin Abdulvehhab es-Sübkî, Tabakâtu'ş-şafiìyyeti'l-kubra, thk. Mahmud Muhammed et- Tanahî -Abdulfettah Muhammed el-Hulvu, (Hecer: 1413), 2/93.

${ }^{26}$ Abdullah b. Muhammed el-Belevî, Siretu Ahmed b. Tolun, thk. Muhammed Kürt Ali, (Kahire: Mektebetu's-Sakkâfeti'dDiniyye, ts.), 350.

${ }^{27} \mathrm{Bu}$ zat çok hadis rivayet eden sika bir hafızdır. ed-Dehlevî, Muhammed Yusuf, Emani'l-ahbar şerhu maâni'l-âsar, (Hind: 1436), 11-26.

${ }^{28} \mathrm{Bu}$ zat Kütub-i Sitteden Sünen'in sahibidir. Hadiste imamdır. Ayrıntılı bilgi için bk. Ahmed b. Muhammed b. İbrahim b. Ebu Bekir İbn Hallikân, Vefeyâtü'l-a yân ve enbâ'ü ebnâ'i'z-zamân mimmâ sebete bi'n-naḳl evi's-semâ' ev eșbetehü'l- 'ayân, thk. İhsan Abbas, (Beyrut: Dar Sadr, 19949), 1/77.

${ }^{29}$ Kureşî, el-Cevahir, 1/274.
} 
264),.$^{30}$ Bahr b. Nasr b. Sabık el-Havlânî (ö. 267), ${ }^{31}$ Bekkar b. Kuteybe (ö. 270), Ebu Bekir el-Bekravî elBasrî, ${ }^{32}$ Rabi' b. Süleyman b. Davud el-Cizî Ebu Muhammed el-Misrî,,33 Rabi' b. Süleyman b. Abdulcebbar (ö. 280), ${ }^{34}$ Ruh b. Farec (ö. 282) el-Kattân Ebu'z-Zenba' el-Mısrî, ${ }^{35}$ Ebu Hazım el-Kadı, ${ }^{36}$ Muhammed b. Şâzan el-Kadı (ö. 274), Ebu Bekir el-Cevherî̉ ${ }^{37}$ Abdülgani b. Rifaâ, ${ }^{38}$ Harun b. Said elEylî, ${ }^{39}$ Yunus b. Abdüla'lâ, ${ }^{40}$ Muhammed b. Abdullah b. Abdulhekem, İsa b. Mesrud, İbrahim b. Munkîz, Mikdam b. Davud er-Rûaynî, Ahmed b. Abdullah b. Berkî, Muhammed b. Âkil el-Firyabî, Yezid b. Sinan el-Basrî, Kadı Ahmed b. Ebu Îmran el-Hanefî̀ ${ }^{41}$ bunlardan bazılarıdır. Görüldüğü gibi o, Şafiî mezhebine mensup bir ailedendir ve yetişmesinde etkili olan hocalarının çoğu da bu mezhebe bağlı alimlerdir. Özellikle dayısı ve hocası Müzenî İmam Şafiî̀den sonra mezhebin en etkili fıkıhçısıdır. Geriye kalan diğer hocaları da hadis ilmiyle meşhur olmuş alimlerdir. Hanefî mezhebine mensup bazı hocaları da daha çok hadis ve fıkıhla iştigal eden şahsiyetlerdir. Böylece yetiştiği bölgenin ilmi geleneği ve ders aldığı hocalarından etkilenmiş ve akaide dair te'lif ettiği eserinde daha fazla nassa dayanan bölge ulemasının yöntemini kullanmıştır. Dolayısıyla Ehl-i rey'in takdirini kazandığı gibi Ehl-i hadisin de takdirini kazanarak her iki ekolün birbirine yakınlaşmasında etkili olmuştur denilebilir.

Hanefî fıkhına mensup itikatta Mu 'tezîlede olan mihne kadıları ilk Abbasî halifelerinin desteğiyle bölgedeki Sünnî âlimleri resmi görevlerden aldırmış ve her türlü baskıya maruz bırakmışlardı. ${ }^{42}$ Onların kadı oldukları mahkemelerde Süleyman b. Rabi’ el-Muradî (öl. 270/885), el-Büveytî (öl. 231/845), Yunus b. Ebdü'la'la es-Sâdefî (öl. 264/883), İbn Abdülhakim b. A‘yun (öl. 260/879) gibi İmam Şafiî’nin öğrencileri de sorgulanmışlardır. Özellikle bölgenin en saygın alimi addedilen İmam Şafiî̀nin öğrencisi el-Büveytî Mısır'dan Bağdat'a kadar prangaya vurularak götürülmüş ve hapse atılarak orada vefat etmiştir.43 Fakat Abbasi halifesi Mütevekkil (ö. 247/861) hilafet makamina geldiğinde, Hanefîliğin Ebu Yusuf, Muhammed dönemi ve mihne sürecinde devletten aldığı desteği sonlandırmış

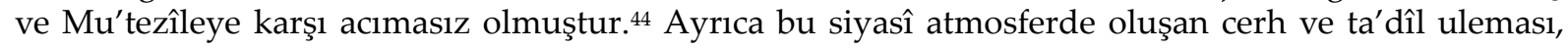
kelamla ilgilenen ve özellikle halku'l-Kur'ân anlayışını benimseyen Hanefîleri sika kabul etmeyip, görüşlerinin çarpıtılarak eleştirilmelerine, toplumda gözden düşürülmelerine ve itibar kaybetmelerine sebebiyet vermiştir. Sonuçta Irak bölgesindeki Hanefîlerin etkinlikleri ve sayıları hızla azalmış ve bölgede tutunamamışlardır. ${ }^{45}$ Görüldüğü gibi fıkıhta Hanefî olan mihne kadılarının ilk dönem Abbasî halifelerinin destekleriyle Mu'tezîlenin görüsslerini ulemaya dayatması sonucunda mezhep aleyhine oluşan reaksiyon ve halife Mütevekkil'in seleflerinin aksine bir tutum takınarak Hanefîliğin bölgede

\footnotetext{
${ }^{30}$ Bu zat İmam Şafiî’nin öğrencisi, görüşlerinin ravisi ve et-Tahâvî’nin dayısıdır. Ayrıntılı bilgi için, bk. İbrahim b. Ali eşŞirazî, Tabakatu'l-fukaha, thk. İhsan Abbas, (Beyrut: Daru'r-Raid, 18970), 97.

${ }^{31}$ Bu zat İmam Şafiî̀nin öğrencisidir. bk. Muhammed b. Ahmed b. Osman ez-Zehebî, Tezkiretu'l-huffaz, (Beyrut: 1998), 3/808.; İbn Hacer Ahmed el-Askalânî, Takribu't-tezhib, (Beyrut: 1395), 1/93.

${ }^{32}$ Hanefi fakihtir. Mısır'da kadılık yapmış, sika ve güvenilir bir kişidir. İbn Hallikân, Vefeyât, 1/279.

${ }^{33}$ Sika, salih ve güvenilir bir kişidir.; Şirazî, Tabakât, 99.

34 İmam Şafiì'nin öğrencisi ve görüşlerinin ravisidir.; a.mlf., Tabakât, 98.

35 Tahâvî'nin kıraat şeyhidir. Ahmed b. Muhammed b. Selame Ebu Cafer et-Tahâvî, Müşkili'l-asâr, thk. Şuayb Arnavut, (Beyrut: Daru'r-Risale, 1994), 1/53.

${ }^{36}$ Hanefî fakihlerinin büyüklerindendir. Vara sahibi sika bir zattır. Şirazî, Tabakât 141.

${ }^{37}$ Hanefi fıkıh imamlarındandır. Kadı Bekkar'ın vekili ve daha sonra yerine geçen alimdir. Muhammed b. Yusuf Ebu Amr elKindî, el-Vullati ve kitabi'l-kuddat, (Beyrut: Matbaa Âba el-Yesuîyin, 1908), 513.

${ }^{38}$ Ebu Davud bu zattan hadis rivayet etmiştir.; Zehebî, Tarihu'l-İslam ve Vefiyatu'l-Meşahiri ve'l-Â'lam, (Beyrut: 2003), 6/115.

${ }^{39}$ Muslim, Ebu Davut, Nesaî ve İbn Mace bu zattan hadis rivayet etmişlerdir. Askalânî, Tehzibu't-Tehzib, (Haydar Abad: 1326), $10 / 441$.

40 İmam Şafî̀'nin öğrencisidir.

${ }^{41}$ Zehebî, Siyaeru A'lamu'n-Nubela, (Beyrut: Daru'r-Risale, 1985), 17/32.

${ }^{42}$ Ebu'l-Mahasin Yusuf İbn Tagribirdî, en-Nücumu'z-zahire fi mülüki Mısre ve'l-Kahire, 1. Bas. (Kahire: Daru'l-Kütübi'l- Misriyye, 1929), 2/280.

${ }^{43}$ Bûveytî'nin bağlı olduğu zincirlerin 40 ritl (şerî ritl yaklaşık 302 gramdır) olduğu rivayet edilir.

${ }_{44}$ Mahmut Akpınar, "Mütevekkil-Alellah, Ca'fer b. Muhammed" TDV İslam Ansiklopedisi, (İstanbul: Diyanet Vakfı Yayınları, 2006), 32/112-214.

${ }^{45}$ Halku'l-Kur'ân anlayışı ve Mihne'nin cerh ve ta'dîle etkisi için bk. Abdu'l-Fettâh Ebû Gudde, Halk-ı Kur'ân meselesi raviler, muhaddisler ve ta'dîl kitaplarma tesiri', çev.: Mücteba Uğur, AÜIFD, Ankara 1975, c. XX, ss. 307-321.; Watt W. Montgomery, İslâm Düşüncesinin Teşekkül Devri, (İstanbul: Sarkaç Yayınları), 352-353.; Mehmet Ümit, “Mihne Sürecinde Hanefîler” Hitit Üniversitesi İlahiyat Fakültesi Dergisi, 2010/1, c. 9, sayı: 17, 125.; İhsan Timur, “Matürîdîliğin Batıda Taban Bulmasında el-Âkidetu'tTahâvîyye'nin Rolü" (Toplum Bilimleri), Ocak-Haziran 10 (19), 329.
} 
dışlanması, ${ }^{46}$ Tahâvî'yi bu yöntemle eser te'lif etmeye sevk etmiştir. Bunun yanında İmam Ebu Hanife'nin çağdaşları olan İbn Ebu Leyla, Süfyan es-Sevrî, Şerik ve Hasan b. Salih gibi bazı muhaddislerin onun iman tarifi ve istidlâl yöntemine yönelik sert eleştirileri hatta sözlü saldırıları ${ }^{47}$ mezheplerin oluşum sürecinde, yeniden tedavüle girmiş olmalı ki; Hanefîlik bu dönemde, merkezde hem fıkhî hem de itikadî açıdan bir duraklama yaşamıştır. İşte Tahâvî bu durumun da farkına varmış olmalı ki, Akaid metni'in hemen başında, 'bu beyanlar Ehl-i sünnet ekolü itikadının, milletin fukahası Ebu Hanife, Ebu Yusuf ve Muhammed'in mezhebine göre açıklanmasıdır' kaydını düşmüştür. ${ }^{48}$ Tahâvî'nin bu ibaredeki kelimeleri çok dikkatle seçtiği görülmektedir. O, ilk olarak görüşlerin Sünnî görüşler ve İmam Ebu Hanife, Ebu Yusuf ve Muhammed'in mezhebine göre olduğunu dile getirmiştir. Ebu Yusuf ve Muhammed'in hadisçi kimlikleri de göz önüne alındığında, İmam Ebu Hanife'yi onlarla zikrederek katı nassçı muhaddisleri bir nevi yatıştırmaya çalışmıştır denilebilir. Zira İmam Ebu Hanife'nin hadisçiliği hususunda meydana gelen eleştiriler sürekli bu iki talebesinin hadis bilgileriyle bertaraf edilmeye çalışılır. İşte Tahâvî'nin burada yapmak istediği şey de bu olduğu söylenebilir. Çünkü Ebu Yusuf ve Muhammed'in hadisçi kimliklerine eleştiri olmamıştır. Dolayısıyla bazı hadisçilerin, adı geçen bu iki hadisçiyle faaliyet gösteren İmam Ebu Hanife'ye eleştirileri de haksız ve yersizdir. Bu yöntemle, bir taraftan mezhebin Sünnî oluşum ile bağları güçlendirmeye çalışırken diğer taraftan İmam Ebu Hanife ve yöntemini takip eden kelam fırkalarını da Sünnî topluluğun bir parçası olduklarını genel çoğunluk tarafından benimsenmesine katkı sağlamıştır.

Tahâvî yukarıda geçen beyanlarla ayrıca mihne kadılarının fıkıhta Hanefî oldukları halde itikatta Hanefî olmadıklarını, Hanefî mezhebine intisap edenlerin itikat alanında Ehl-i hadisle bazı farklılıkları olsa da Sünnîliğin diğer kolunu temsil ettiklerini ifade etmek istediği kuvvetle muhtemeldir. Bu yolla Hanefî fıkıh mezhebine mensup Mutezilî kadıların mihne mezaliminde edindikleri kütü imajın Mu'tezîle görüşlerini benimsemeyen halis Hanefîler üzerindeki etkisi kırılmaya çalışılmış ve Mu'tezîlî kelamî kimliklerine yönelik olmuştur. Ayrıca Hanefîliğin fıkhı yanında İmam Ebu Hanife, Ebu Yusuf ve Muhammed yoluyla gelen itikadî görüşlerinin de olduğunu ve bu görüşlerin Sünnî görüşler olduğunu ifade etmiştir. Akaide dair yazdığı eseri birkaç sayfadan ibaret olmasına rağmen her üç Sünnî fırka ulemasının kabulüne mazhar olmuştur. Nitekim o tarih ve tabakat eserlerinin hemen hemen hepsinde yerini almış ve sitayişle zikredilmiş, yaşadığı dönemden günümüze kadarki tarihi süreçte Sünnî oluşum ulemasının takdirini kazanmıştır. Bu doğrultuda o daha hayattayken çağdaşı Mısır tarihçisi ve Şafiî âlim İbn Yunus (ö. 347) onu takdir etmişs9 ve aynı şekilde Şafiî âlim İbn Asâkir onun için, 'sika, sabit, akıllı bir fakihtir. Ondan sonra gelecekler arasında yerini tutacak bir kimse yoktur', ${ }^{50}$ İbn Nedim ise onun için 'evhadu'z-zaman (yaşadığ zamanda eşi ve benzeri olmayan)' tabirini kullanmıştır. ${ }^{51}$ Hanefîlerden İbn Kemal Paşa, 'Hanefî fikhında üçüncü tabakadandır. Mutlak müçtehit olan Ebu Hanife her hangi bir konuda fikir beyan etmemiş ise o konuda müstakil bir müçtehit olarak Tahâvî fikir beyan edebilecek konumdadır' demiştir.52 Ebu Hanife ashabının Mısır'daki riyaseti kendisinde olan sika, fakih ve imam ${ }^{53}$ sika, sabit, fakih ve yerini tutacak başka birisi olmayan, Kûfîlerin (Hanefîlerin) siyerini ve haberlerini en iyi bilen, bununla beraber diğer bütün mezhepleri de bilen kişij ${ }^{4}$ ayrıca Hanefî kelam geleneğinde te'lif edilen eserlere referans olan bir akaid yazarı ${ }^{55}$ şeklinde Sünnîliğin alt kolları olan Şafîi ve Hanefî âlimlerce ilimdeki otoritesine işaret edilmiş ve taltif edilmiştir.

\footnotetext{
46 İbn Kesir, el-Bidâye, 10/295.

${ }^{47}$ Hatip, İbn Ebu Leyla'nın, 'senin şahitliğini hiçbir zaman kabul etmeyeceğim', Süfyan es-Sevrî̀nin, 'hiçbir zaman seninle konuşmayacağım', Şerik'in, 'şayet hüküm sahibi olsaydım boynunu vururdum' ve Hasan b. Salih'in 'senin yüzüne bakmak bana haram olsun' şeklinde İmam Ebu Hanife’ye sözlü saldırıda bulunduklarını ifade eder. Ayrıntılı bilgi için bk. Hatib, elBağdadî, Tarihu Bă̆gat, thk. Abdulkadir Âta, (Beyrut: Daru'1-Kutübi'l-illmiyyah, 1997), 13/370.

${ }^{48}$ Ahmed b. Muhammed et-Tahâvî, el-Akidetu't-tahâvîyye beyanu akideti ehli's-sünneti ve'l-cemaat, (Beyrut: Dar İbn Hazm, 1995$), 7$.

${ }^{49}$ Abdurrahman b. Ahmed b. Yunus es-Sâdefî, Tarihu ibn Yunus el-Misrî, (Beyrut: 1421), 1/22.

${ }^{50}$ Ali b. Hasan b. Hibbetullah İbn Asâkir, Tarihu Dımaşk, (Beyrut: 1995), 7/368.

${ }^{51}$ Muhammed b. İshak İbn Nedim, el-Fihrist, (Beyrut: Daru'l-Ma'rife, ts.), 292.

52 Ahmed b. Süleymen Şemsuddin İbn Kemal Paşa, Tabakâtu'l-müçtehidin, thk. Ebu Abdurrahman b. Akîl, (Kahire: Cebelavi, 1397), 9.

${ }^{53}$ Hüseyin b. Ali B. Muhammed es-Sâymirî, Ahbaru Ebi Hanife ve ashabihi, (Beyrut: 1985), 168.; Muhammed b. Yusuf b. Yakub elYemenî, es-Sülûk fi tabakâti'l-ulemai ve'l-mülûk, (San'a: 1995), 1/220.; Selahaddin Halil b. Ebik b. Abdullah es-Sâfedî,, el-Vafi bi'lVefiyyat, (Beyrut: 2000), 8/8.

${ }^{54}$ Kasım Zeyneddin İbn Kutluboğa, Tacu't-Terâcüm, (Dımaşk: 1992), 100.

55 En önemli Hanefî/Matürîdî kelamcı Nesefî bunu Tabsira'da dile getirir.; Nesefî, Tabsira, 1/467.
} 
Tahâvî Sünnî fırkaların aynı isimle anılmasında Akaid metni dışında diğer eserleri bağlamından da etkili olmuştur. $O$ temel İslam bilimlerinin çoğunda değerli eserler vermiştir. İbn Asâkir onun, İhtilafu'l-ulema", eş-Şürut", "Ahkamu'l-Kur'an" ve "Maâni'l-âsâr" adlı eserlerinden söz eder.56 Kaynaklarda adı geçen fakat günümüze kadar basılmayan bazı eserleri olduğu gibi günümüze ulaşmış ve baskısı yapılmış birçok eseri de vardır. ${ }^{57}$ Ahkamu'l-Kur'ani'l-Kerim, ${ }^{58}$ İhtilafu'l-ulemâ, ${ }^{59}$ etTesviyye beyne haddesena ve ahberena, el-Camiu'l-kebir fi'ş-şürut, es-Süneni'l-me'sure, ${ }^{60}$ Şerhu meâni'l-âsâr, ${ }^{61}$ Sahihu'l-asâr, eş-Şurutu's-sâgir, ${ }^{62}$ el-Âkidetu't-tahâvîyye (Akaid Metni), Muhtasaru't-tahâvô̂์ ve Müşkili'lasâr ${ }^{64}$ adlı eserlerdir. Eserler göz önüne alındığında ağırlıklı olarak hadis ve fıkıh içerikli oldukları görülmektedir. Akaid alanında sadece bir tane eseri olmuştur, fakat eser her üç Sünnî fırkanın kabulüne mazhar olduğu için kendisine şöhret kazandırmıştır.

Sübkî'nin Tabakatı'ş-Şafî̀yye adlı eserinde "Tahâvî Akidesi ve Eş'arî itikadı arasında sadece üç meselede manevi ihtilaf olduğu, diğer konularda görüş birliğinde olduklarını" ifade etmesi, dönemin Eş'arî kelamcıları tarafından onun akidesinin benimsenmesi hususuna katkı sağlamıştır. ${ }^{65}$ Eser hilafet merkezi ve yakın çevresindeki Ehl-i rey ve Ehl-i haddisin de dikkatini çekebilmiştir. Böylece o, Sünnî oluşumun Ehl-i rey ve Ehl-i hadis taraflarının birleştirilmesi hususuna katkı sağlamıştır denilebilir. Nitekim Şerh ve haşiyecilik döneminin başlamasıyla aşağıda görüleceği gibi büyük bir kısmı Mâtürîdî kelamcılar olmak üzere diğer fırka kelamcıları da eserle ilgilenmiş ve sonuçta Akaid Metn'i şerh literatürü oluşmuştur. Ayrıca eserinin sonunda, "Allah'tan bizi iman üzere sabit kılmasını, imanla (hayatımızı) sonlandırmamızı (nasip eylemesini), muhtelif heva ve hevese tabi görüşlerden ve Müşebbihe, Mu'tezîle, Cehmiyye, Kaderiyye gibi doğru yolda olmayan, Ehl-i Sünnet ve'l-Cemaat'a muhalif olan ve dalâlete yandaş olan mezheplerden korumasını diliyorum. Biz onlardan beriyiz. Bize göre onlar dalâlete çokça sevk eden ve düşük olanlardır" ifadesini kullanır. ${ }^{66} \mathrm{O}$ bununla bir taraftan Sünnî oluşum dışında kalan fırkaların adını da zikrederek ayırmış diğer taraftan Sünnîliğin bir çeşit çerçevesini de çizmiştir denilebilir. Böylece sistematik Sünnî kelamın zeminini de hazırlamıştır.

Memlüklerle başlayan şerh ve haşiyecilik döneminde Hanefî ve diğer Sünnî kelam alimleri esere birçok şerh yazmışlardır. ${ }^{67}$ Bunlar arasında Mâtürîdî düşüncesinde olanlar,
1. İsmail b. İbrahim eş-Şeybanî (öl. 629/1232) el-Beyan: I'tikâdu ehl-i's-sünneti ve'l-cemaâti, ${ }^{68}$
2. Necmeddin Baybars b. Yalınkılıç Abdullah et-Türkî (öl. 652/1255) en-Nuri'l-lamı' ve'l-burhani's-
3. Mahmud b. Ahmed el-Kûnevî ed-Dimaşkî el-Hanefî (öl. 771/1369) el-Kâlaid fi şerhi 'l-akaid, ${ }^{70}$
4. Hibbetullah b. Ahmed b. Ma'lî et-Türkistanî’nin (öl. 733/1332) şerhi, ${ }^{71}$
5. Ömer b. İshak el-Hindî el Gaznevî’nin (öl. 773/1372) Serhu akaidi't-Tahâvîyye, ${ }^{72}$
6. Muhammed b. Muhammed el-Babertî (öl. 786/1384) Şerhu akideti ehli 's-sünne ve 'l-cemaâti, ${ }^{73}$ sâtı, 69

\footnotetext{
56 İbn Asâkir, Tarihu Dımaşk, 7/369.; Zehebî, Tezkiretu'l-Huffaz, 3/21.

57 Abdullah Nezir Ahmed, Ebu Ca'fer et-Tahâvî el-imamu'l-muhaddisu'l-fakîh, (Dımaşk: Daru'l-Kalem, 1991), 206.

58 Sadettin Ünal'ın tahkikiyle yayınlanmıştır.

59 Hanefî usülcü Cessâs'ın aynı adla muhtasar ettiği eserdir.

${ }^{60}$ Tahâvî bu eseri dayısı Müzenî'den rivayet etmiştir. Bu esere Sünenu'ş-Şafii de denir.

${ }^{61}$ İki defa basılmıştır. Birinci baskı iki cilt şeklinde Hind 1302, ikinci baskı Muhammed Zührî en-Neccar ve Muhammed Seyyid Cadu'l-Hak tarafından dört cilt tahkik edilerek Mısır h. 1387 tarihinde basılmıştır.

${ }^{62}$ Ruhi Özcan tarafından tahkiki yapılmış ve Irak Divanu'l-Evkaf kurumu tarafından Bağdat h. 1394 tarihiyle basılmıştır.

${ }^{63}$ Ebu'l-Vefa el-Afganî'nin tahkikiyle Haydarabad ed-Deken Hint tarihsiz, Kahire'de Daru'1-Kütubi'l-Arabiyye h. 1370 tarihinde basılmıştır.

64 Şuayb Arnavut eserin bir kısmını tahkik ederek Beyrut 1408 tarihinde neşretmiştir.

${ }^{65}$ Abdulvehhab Tacuddin es-Sübkî, Muidi'n-niâm ve mubidi'n-nikâm, (Beyrut: Multezemu'l-Kütup es-Sakâfiyye, 1982), 3/377.

${ }^{66}$ Tahâvî, Akide, 32.

${ }^{67}$ Şerh dönemi Memlükler dönemiyle başlamaktadır. bk. Mustafa Sinanoğlu, "Şerh", Tdv İslâm Ansiklopedisi, https://islamansiklopedisi.org.tr/serh/5-kelam (05.11.2019).; Ömer Feruh, Tarihu'l-Edebil'-Arab̂̀, (Beyrut: 1979), 3/616.

${ }^{68} \mathrm{Bu}$ eserin tahkiki Abdulaziz İzeddin es-Seyrevanî tarafından yapmıştır. Riyad'da Daru'r-Reşit tarafından (birinci baskısı) $\mathrm{h}$ 1413 de basılmıştır.

${ }^{69}$ Laleli 2318, Köprülü 2/1861, 848 numarayla kayıtlı bulunmaktadır.

${ }^{70}$ H. 1311 tarihinde Kazan' da basılmıştır.

${ }^{71}$ Amman Daru Nuru'l-Mubin Li'n-Beşri ve't-Tavzi' de Cadullah Besam Salih tarafından tahkikli neşredilmiş ve 1. Bas. 2014 tarihinde yapılmıştır.

${ }^{72}$ Kahire 2009'da Daru'l-Kürz tarafından basılmıştır.

${ }^{73}$ Arif Aytekin tahkikini yapmıştır. 1. Baskısı Kuveyt Vakıflar ve Din İşleri Bakanlığı tarafından basılmıştır.
} 
7. Muhammed b. Ebu Bekir el-Ğuzî el-Hanefî İbn Binti'l-Himyeri (Sahâvî'nin öğrencisidir) Şerhu akaidi' ${ }^{-}$-Tahâvî, ${ }^{74}$

8. Abdulgani el-Ğunaymî (öl. 1394) Şerhu akaid't-Tahâvîyye, ${ }^{75}$

9. Seyfu'd-Devle en-Nasirî̀nin (758/1356 civarı) emriyle yazılmış, müellifi mechul bir şerh, ${ }^{76}$

10. Mahmud b. Muhammed el-Kunstantinî (öl. h. 916/1510) Şerhu akidetu't-Tahâvî,

11. Şeyhzade Abdurrahim b. Ali el-Amasî (öl. h. 944/1537) Şerhu akaidi't-Tahâvîyye,

12. Hasan Kâfî Akhisarî (öl. h. 1025) Nuru'l-yakîn fi usuli'd-din,

13. Abdulgani el-Meydanî (öl. h. 1222) Şerhu akideti't-Tahâvî gibi şerhler.

Selef düşüncesi paralelindeki şerhlerden en önemlisi Ali b. Ali b. Muhammed b. Ebi'l-Îz elHanefî'ye (öl. 792) ait Şerhu âkidetu't-tahâvîyye' adlı eserdir. ${ }^{78}$ Ayrıca bu ekole intisap eden birçok yazar da şerh yazmışlardır. Muhammed b. Mani' (öl.1385), Abdulaziz b. Baz, Muhammed Nasiruddin elElbanî, Abdurrahman el-Berrak, Abdullah el-Güneyman, Salih İbn Fûzan, Abdulaziz er-Racihî, Salih Alu'ş-Şeyh, Ahmet b. Sa'd el-Ğamidî, Muhammed el-Humeyyis gibi şarihler bunlardan bazılarıdır.

Eş‘arî düşüncesi paralelinde olan bazı şerhler ise,

1. Hasan b. Ali es-Sakkaf (öl. 1335) Sahihu şerhi'l-akaid't-Tahâvîyye

2. Abdullah Herurî el-Habeşî İzharu'l-Âkidetu's-Sunnîyye bi Şerhi'l-akideti't-Tahâvîyye ve ed-Dureru'lbehiyye fi halli elfazi'l-akideti't-tahâvîyye adlı iki şerhi ${ }^{79}$

3. Said Abdullatif el-Fûda'nın eş-Şerhu'l-kebir ala'l-akideti't-Tahâvîyye ${ }^{80}$

4. Cabir Cibran'ın et-Ta'likâti's-sünnîyye âla 'l-âkideti 't-Tahâvîyye adlı şerhlerdir. ${ }^{81}$

Görüldüğü gibi Sünnî ekolün Ehl-i hadis, Ehl-i rey ve Selefî fırkalarının âlimleri Tahâvî'nin Akaid Metni'ne onlarca şerh yazıp Tahavî Akaid'i Şerh Literatürünü oluşturmuşlardır. Esasen Sünnîlikle anılan bu üç ekol ulemasının ilk dönemden itibaren Tahâvî ve eserine verdikleri ehemmiyet onun Sünnî ekolun oluşum ve gelişimine sunduğu birleştirici katkıları sebebiyle olmuştur denilebilir. Böylece onun ümmetin büyük çoğunluğunun Sünnî oluşum olarak tek isimle ve bir fırka gibi algılanmasında önemli katkılar sağladığı söylenebilir.

\section{SONUÇ}

Hz. Peygamber ve Sahabe döneminde diğer İslami ilimlerin kaynak Kur'an ve Sünnet olduğu itikat ilminde de kaynak Kur'an ve Sünnet olmuştur. Fakat h. I. Yüzyılın sonlarına doğru bazı kelamcılar artık nass ile yetinmeyip felsefî ve akli delillerle akaid konularını açıklamaya çalışmışlardır. Bu sebeple İmam Ebu Hanife itikadî konuları nassın yanında aklî delillerle de açılamayı zorunlu görmüştür. İbn Küllâb, Haris el-Muhâsibî, el-Kerâbîsî, el-Kalânisî gibi bazı Sünnî kelamcılar da onun yöntemini benimseyerek Sünnî kelamcıların selefleri olarak yerlerini almışlardır. Eş'arî ve Mâtürîdî ise onun yöntemiyle Sünnî akaidini sistematik kelama dönüştürmüşlerdir. Böylece Sünnî ekolün fıkıhla beraber sistematik kelamı meydana gelmiştir. Fakat Ehl-i hadisi temsilen Eş'arîyye ve Hanefî itikat ekolünü temsilen Mâtürîdîyye şeklinde iki fırka olarak gelmişlerdir.

Eş'arî ve Mâtürîdîyle aynı dönemde yaşayan Tahâvî de Sünnî kelama çok önemli katkılar sunmuştur. O Şafîilikten Hanefîliğe geçmişse de yetiştiği çevrenin etkisinde kalmıştır. Böylece o bir taraftan İmam Ebu Hanife, Ebu Yusuf ve Muhammed'in itikadî görüşlerini beyan ederek, SünnîHanefî itikat geleneğine katkı sunmuş diğer taraftan te'lif ettiği eserlerle, eğitimini aldığı Şafiî ulemasının taltifine mazhar olmuştur.

Tahâvî'nin Sünnî ekole olan katkısına gelince, istidlâl yönteminde nassa daha yoğunluklu dayandığı gibi aynı zamanda İmam Ebu Hanife, Ebu Yusuf ve Muhammed'e tabiiyetini dile getirerek İmam Ebu Hanife'nin kelam alanındaki istidlâl yöntemini de kullanmıştır. Ayrıca mihne kadılarının fıkıhta Hanefî kimlikleriyle, halk nezdinde Hanefîliği Mu'tezîle fırkasıyla özdeş görülmesini, Hanefî

\footnotetext{
${ }^{74}$ Muellifine ait el yazması Dımaşk Acüriyye 103ütüphanesinde bulunmaktadır.; Abdulğani Ğuneyman, Şerhu akideti Tahâvî, thk. Muhammed Muti` Hafız ve Muhammed Riyad Malih, (Beyrut Daru'l-Fikir -Dımaşk: 1992), 10.

${ }^{75}$ Dımaşk Daru'l-Fikir, 1992 de 2. Baskısı yapılmıştır.

${ }^{76}$ Bir nüshası Cûta 665 ve Hindi Kütuphanesi 4569 numarada kayıtlıdır.

77 Haci Halife (Katip Çelebi) bu eserin varlığından söz etmektedir.; bk. Hacı Halife, Keş̧fu'z-zunun an usami'l-kitabi ve'l-fünun, (Beyrut: Daru İhyai't-Turasi'l-Arabî, ts.), 2/1143.

${ }^{78}$ Abdullah b. Abdurrahman b. Abdullah el-Cebrîn tarafından tahkik edilerek 1. Baskısı Riyad Dar es-Sûmey'î 2010 yılında basılmıştır.

${ }^{79}$ Beyrut 1998 tarihinde Şirketu'l-Meşâri'li'n-Neşri ve't-Tevzi' matbaasında basılmıştır.

${ }^{80}$ Beyrut'ta Daru'z-Zahair adlı matbaada tarihsiz basılmıştır.

${ }^{81}$ Mekke' de Daru'l-Ûlumu'd-Dinîyye matbaasında tarihsiz basılmıştır.
} 
imamların adını vurgulu bir şekilde zikrederek, ortadan kaldırarak mezhebin yeniden Sünnî kimlikle anılmasını sağlamış ve Mutezilî Hanefîlerin mihnede sebep oldukları itibar kaybının yeniden Sünnî Hanefîliğe geri kazanılmasını da sağlamıştır. Akaide dair te'lif ettiği eserin ümmetin büyük çoğunluğu tarafından kabul görmesi bunu göstermektedir. Böylece bu ulemanın itikadî görüşlerinin Sünnî mezhebin görüşü olduğunu topluma kabul ettirmiştir. Nitekim yaşadığı dönemden itibaren Sünnî ekolün her bir koluna ait tabakat eserlerinde en önde yerini almıştır.Onun "Âkaid metni"ne Maturidî ve Eş'arî kelamcılar onlarca şerh yazmıştır. Bunun yanında günümüzde daha güçlü bir sahiplenmeyle, Selefî düşüncesindeki âlimler de pek çok şerh yazmışlardır. Böylece Tahâvî, Eş'arî, Mâtürîdî ve Selefî fırkaların Sünnî oluşum bünyesinde yer bulmasına katkı sağlamıştır.

\section{KAYNAKÇA}

Abdullah Nezir Ahmed. Ebu Ca'fer et-tahâvî el-imamu'l-muhaddisu'l-fakîh, Dımaşk: Daru'l-Kalem, 1991.

Aburezzak, Mustafa. Temhidun li Tarihi'l-Felsefeti'l-İslamiyye, Kahire: Mektebetu İskenderiyye 2010.

Akpınar, Mahmut. “Mütevekkil-Alellah, Ca'fer b. Muhammed” TDV İslam Ansiklopedisi, İstanbul: TDV Yayınları 2006.

Askalânî, Ahmed İbn Hacer. Tehzibu't-tehzib, Haydar Abad: 1326.

Bağdadî, Abdulkahir b. Tahir b. Muhammed. el-Farku beyne'l-firak, Beyrut: Daru'l-Kutubi'l-Îlmiyyah, ts.

Belevî, Abdullah b. Muhammed. Siretu Ahmed b. Tolun, thk. Muhammed Kürt Ali, Kahire: Mektebetu's-Sakkâfeti'd-Diniyye, ts.

Berbeharî, Hasan b. Ali b. Halef. Şerhu's-sünneti, Riyad: 1426.

Cündî, Muhammed b. Yusuf b. Yakub, el-Yemeni. es-Süluk fi tabakatı'l-ulemai ve'l-müluk, San'a: Daru'nNeşr 1995.

Dakâr, Abdulgani. el-İmamu'ş-Şafii fakîhu's-sunneti'l-Ekber, Beyrut: Daru'l-Kalem Dımaşk ve Daru'şŞamiyye 1996.

Darimî, Osman b. Said b. Halid. Nakdu'l-İmam Ebu Said Osman b. Said âla'l-merisî el-cehmî el-ânid fima eftere âla'llahi azze ve celle mine't teohid, Riyad: Daru Neşr 1998.

Dehlevî, Muhammed Yusuf. Emani'l-ahbar şerhu maâni'l-asâr, Hind: 1436.

Ebû Gudde, Abdu'l-Fettâh. Halk-ı Kur'ân Meselesi Raviler, Muhaddisler ve Ta'dîl Kitaplarına Tesiri, çev.; Mücteba Uğur, Ankara: AÜİFD 1975.

Ebu Hanife, Numan b. Sabit. el-Âlim ve'l-müteâllim, Çev: Mustaafa Öz, İstanbul: MÜİF Vakfı Yayınları 2015.

Eş'arî, Ali b. İsmail Ebu'l-Hasan. Kitab el-lûma', thk., İzeddin es-Seyrevan, Beyrut: 1987.

Feruh, Ömer. Tarihu'l-Edebil'-Arabî, Beyrut: 1979.

Fığlalı, Ethem Ruhi. Günümüz İslam Mezhepleri, İzmir: İzmir İlahiyat Vakfı Yayınları 2008.

Gazzalî, Muhammed b. Muhammed Ebu Hamid. Kanunu't-te'vil, thk. Muhammed Zahid el-Kevseri, Kahire: Matbaatu Envar 1940.

Haci Halife (Katip Çelebi). Keşfu'z-zunun an usami'l-kitabi ve'l-fünun, Daru Beyrut: İhyai't-Turasi'1Arabi ts.

İbn Asâkir, Ali b. Hasan b. Hibbetullah Ebu'1-Kasım. Tarihu Dımaşk, Beyrut: Daru Fikir 1995.

İbn Hallikân, Ahmed b. Muhammed b. İbrahim b. Ebu Bekir Şemsuddin. Vefeyatu'l-a'yan ve enbau ebnai'z-zaman, thk. İhsan Abbas, Beyrut: Dar Sadr 1994.

İbn Kemal Paşa, Ahmed b. Süleymen Şemsuddin. Tabakâtu'l-müçtehidin, thk. Ebu Abdurrahman b. Akil, Kahire: Cebelavi 1397.

İbn Kesir, İsmail b. Ömer ed-Dımaşkî. el-Bidâyetu ve'n-nihâyetu, thk. Ali Şirî, Beyrut: Daru İhyai Turasi'1-Arabî 1988. 
İbn Kutluboğa, Kasım Zeyneddin. Tacu't-Teracüm, Dımaşk: 1992.

İbn Nedim, Muhammed b. İshak. el-Fihrist, Beyrut: Daru'l-Ma'rife ts.

İbn Tagribirdî, Yusuf Ebu'l-Mahasin. en-Nücumu'z-zahire fi mülüki Mısre ve'l-Kahire, Kahire: Daru'lKütübi'l-Misriyye 1929.

Karadaş, Cağfer. Ana Hatlarıyla Kelam Tarihi, İstanbul: Ensar Neşriyet 2017.

Kevserî, Muhammed Zahid. el-Havî fi Sireti'l-Imam Ebi Cafer et-Tahâvî, Kahire: ts.

Kindî, Muhammed b. Yusuf Ebu Amr. el-Vullati ve kitabi'l-kuddat, Beyrut: Matbaa Âba el-Yesuîyin 1908.

Kureşî, Abdulkadir b. Muhammed b. Nasrullah. el-Cevahiru'l-muzia fi tabakatı'l-Hanefìye, Karatci: ts.

Mâtürîdî, Muhammed b. Muhammed b. Mahmud Ebu Mansur. Kitab et- tevhid, thk. Fethullah Huleyf, Beyrut: Dar Sadr 2007.

Mekkî, Ahmed İbn Hacer. el-Hayratu'l-hisan fi menakibi'l-İmami'l-Â'zam Ebu Hanifetu'n-Numan, Bombay: 1324.

Nesefî, Meymun b. Muhammed Ebu'1-Muin. Tabsiratu'1-Edille fi Usuli'd-Din, Ankara: Diyanet Yayınları 2004.

Neşşar, Ali Sami. Neş'etu'l-fikri'l-felsefi fi'l-İslam, Kahire: Daru'l-Mea'rif ts.

Sâdefî, Abdurrahman b. Ahmed b. Yunus. Tarihu İbn Yunus el-Mısrî, Beyrut: 1421.

Sâfedî, Selahaddin Halil b. Ebik b. Abdullah. el-Vafí bi'l-vefiyyat, Beyrut: 2000.

Sâymirî, Hüseyin b. Ali B. Muhammed. Ahbaru Ebi Hanife ve ashabihi, Beyrut: 1985.

Sem'ânî, Abdulkerim b. Muhammed b. Mansur. el-Ensab, Haydar Abad: Dairetu Maârifi'l-Osmaniyye 1384.

Sübkî, Taceddin Abdulvehhab. Tabakâtu'ş-Şafî̀yyeti'l-Kubra, thk. Mahmud Muhammed et-Tanahî ve Abdulfettah Muhammed el-Hulvu, Hecer: 1413.

Muidi'n-niâm ve mubidi'n-nikam, Beyrut: Multezemu'l-Kütup es-Sakâfiyye, 1982.

Şirazî, İbrahim b. Ali. Tabakatu'l-Fukaha, thk. İhsan Abbas, Beyrut: Daru'r-Raid 1970.

Tahâvî, Ahmed b. Muhammed b. Selame Ebu Cafer. Müşkili'l-Âsar, thk. Şuayb Arnavut, Beyrut: Daru'r-Risale 1994.

Metnu Âkidetu't-Tahâvîyyetu beyanu âkideti ehli's-sünneti ve'l-cemaa, Beyrut: y.y. 1995.

Timur, İhsan. "Mâtürîdîliğin Batıda Taban Bulmasında El-Âkidetu't-Tahâvîyye'nin Rolü", (Toplum Bilimleri) Ocak-Haziran 10 (19).

Topaloğlu, Bekir. Kelam İlmine Giriş, İstanbul: Damla Yayınları 2013.

Ümit, Mehmet. “Mihne Sürecinde Hanefîler" Hitit Üniversitesi İlahiyat Fakültesi Dergisi, 2010/1, c. 9, sayı: 17 .

Watt, W. Montgomery. İslâm Düşüncesinin Teşekkül Devri, Çev.; Ethem Ruhi Fığlalı, İstanbul: Sarkaç Yayınları ts.

Yemenî, Muhammed b. Yusuf b. Yakub. es-Sülûk fi tabakati'l-ulemai ve'l-mülûk, San'a: 1995.

Zehebî, Muhammed b. Ahmed b. Osman b. Kaymaz. Siyaeru a'lamu'n-nubela, Beyrut: Risale Yayınları 1985.

Tezkiretu'l-huffaz, Beyrut: Daru'l-Kütub el-İlmiyyah 1998.

Tarihu'l-İslam ve vefiyatu'l-meşahiri ve'l-a'lam, Beyrut: 2003. 